Article

\title{
Worksheet for Describing and Categorizing a Genocidal Event: A New Tool for Assembling More Objective Data and Classifying Events of Mass Killing
}

\author{
Israel W. Charny \\ Institute on the Holocaust and Genocide, POB 10311, 91102 Jerusalem, Israel; \\ encygeno@gmail.com; Tel.: 972-2-672-0424 \\ Academic Editor: Lisa Hajjar \\ Received: 13 April 2016; Accepted: 29 June 2016; Published: 19 July 2016
}

\begin{abstract}
A new tool is presented for facilitating greater objectivity in the chaotic field of genocide studies: first, assembling the available factual data about any event of mass murder systematically; second, contextualizing each of our judgments of the nature of the crime as a choice being made by a given scholar or institution (e.g., a specific court), but not as "God's word." The Worksheet for Describing and Categorizing a Genocidal Event is believed to be innovative in several ways: (1) This model presents researchers with a methodology for developing systematic, extensive and objective information about many different aspects of an event of mass killing; (2) Emphasis is placed on identifying each researcher's guiding concept of genocide; (3) The proposed methodology purposely postpones any effort at classification-including whether an event constitutes "genocide" - until after factual data have been assembled; (4) Categorization of an event is also to be understood as an act of judgment by each researcher, not as scientifically established truth; (5) It is also to be understood that classification in the language of social sciences is different than legal classifications that in turn also are to be understood as based on whatever specific code of law.
\end{abstract}

Keywords: genocide and mass killing; genocide perpetrators, accomplices and victims; law and genocide; genocide definition; genocide researcher subjectivity

\section{A New Tool and Sequence for Research}

The Worksheet for Describing and Categorizing a Genocidal Event is a new tool and sequence for research (and not another declarative scholarly statement about the definition of genocide) that is presented for facilitating greater objectivity in our chaotic field of genocide studies: first, assembling the factual data as available about any event of mass murder systematically; second, contextualizing each of our judgments of the nature of the crime as a choice being made by a given scholar or institution (e.g., a specific scholar or court), but not as absolute truth.

The Worksheet for Describing and Categorizing a Genocidal Event presents several innovations ${ }^{1}$ :

(1) This model presents researchers with a tool and methodology for developing more systematic, extensive and objective information about many different aspects of an event of mass killing. As far as we know, it provides the first ever systematic worksheet for assembling a wide variety of empirical data about how any given event of genocidal mass killing developed and unfolded

1 The actual Worksheet for Describing and Categorizing a Genocidal Event will be available for use as a supplementary document of this paper. It can be found at www.mdpi.com/2076-0760/5/3/31/s1. 
and its outcomes. There have been some attempts at complex scoring systems, but these would seem to require a team of researchers and computer-generated reports while the present proposal is intended as an everyday working tool for narrative recording and assembling of information even and primarily by a single researcher. Of course, the researcher's assembly of information subsequently can also be submitted to more complex coding and computerizations.

(2) Second, emphasis is placed on identifying the researcher (analyst) who is recording and assembling the data, and on identifying each researcher's guiding concept of genocide. It is to be understood that even assembling data that are as objective as possible takes place in a specific context of each researcher's professional identity and guiding conceptualizations.

(3) Third, the proposed methodology purposely postpones any effort at classification or categorization of an event-whether as constituting "genocide" or not, and whether the mass killings qualify as "intentional genocide," "crimes against humanity," or any of the several other names that have been proposed for describing mass murders. Categorizing is postponed until after factual data about the event have been assembled. What happens too often today is that major energies are poured into the categorizations and even the collection of data about the event falls by the wayside, especially if the event is assigned to whichever kind of "unimportant" or "less important" or a type of mass killing that does not qualify as "genocide."

(4) Now following the collection of actual information about the event-one proceeds to a process of categorization of an event of mass killing - categorization is to be understood as an act of judgment by each researcher, and not as scientifically established truths. Even in the case of legal ruling (e.g., the International Criminal Court ruling that genocide was committed in the slaughter at Srebrenica but that Serbia is not to be accused of genocide) $)^{2}$ is to be understood that judgments are based on the attitudes and philosophy of the persons doing the categorization.

(5) It is also to be understood that classification by a researcher in the language of social sciences is different than efforts at a legal classification. The legal classifications in turn are also to be understood as based on existing codes of law that are formulated differently in the legal codes of different countries and in the international legal system, and also that like all laws, may well see future changes.

Unlike so many of the pseudo-certainties that have been advanced in the fledgling field of genocide studies by different people as if a given event of mass murder obviously and unquestionably can only be defined in a specific way, we move towards a more comprehensive assembly of data about many different aspects of an event of mass killing, and towards a better understanding of the process of judgment by different researchers.

\section{Defining Genocide and the Obstacles of Definitionalism}

So very much of genocide studies has been devoted to argumentation about what is genocide-which definition will triumph, and whether a given event of ugly mass murder of civilians constitutes genocide [1].

One scholar argues in a recent article that the lack of definitional closure and decisiveness has been a prime cause of paralysis in the international system in response to mass murders such as in Rwanda and Sudan [2]. If this is true it compels new solutions. Definitional squabbles and battles result in a loss of much of the simple real meanings of so many people being murdered. Being overly occupied with intellectual disputations and turf power struggles, which has been identified in the literature under the name of "definitionalism," is an anesthetic to feeling the genuine tragedy and

2 See the later discussion of this ruling by the International Criminal Court of Justice on the genocidal massacre at Srebrenica. 
horror of mass murder [1]..$^{3}$ Endless "Is it or is it not genocide?" controversies dull the simple ethical sensitivity that murders most foul have been committed.

The literature includes many conflicting definitions of genocide including a wide-ranging definition of genocide that speaks determinedly to the outcome of many human beings being murdered rather than to the intent, and is not limited to intended total destruction of a people. This definition addresses the basic FACTS that when many unarmed human beings are killed by whomever for whatever "reasons" in whatever ways, genocide has been committed. Quite simply the definition defines any "mass killing of substantial numbers of human beings when not in the course of military action against the military forces of an avowed enemy, under conditions of the essential defenselessness and hopelessness of the victim" as genocide and is entitled "a generic definition of genocide" ([1], p. 76).

Note in a review of a recent book by Joyce Apsel and Ernesto Verdeja [3], Edward Westerman (2014) states definitively: "In Lemkin's view results with respect to targeted populations proved more important than the question of deliberate intent." ([4], p. 114).

The wide-ranging definition then goes on to call for a "multiple classification of genocide," where a selection is made from a variety of types of genocide, each of which conveys information about the nature and extent of the killings, and is further linked to a schema for evaluating weights or gradations of the crime similar to classifications of homicide such as in the first, second or third degree $[5,6] .{ }^{4}$ Thus, Cultural Genocide is not the same as Genocidal Massacre which is not the same as Intentional Genocide, and so on. Several different categories are included in the Worksheet. (See Appendix A for a brief survey of many of the key definitional categories and sub-categories that have been proposed in the literature of genocide studies to date).

The prevailing responses to this definition that appear in one form or another in the literature of genocide studies have been that this definition is too broad, that it defines every event of mass killing as "genocide," hence that the power and awe of the special horrendous category of "genocide" are seriously diminished. These critiques argue that the concept is meaningless unless the definition of genocide is restricted to the different restrictions chosen by various scholars, and at least one scholar is so extreme that he even rules out all but one genocide, the Holocaust, from constituting genocide [7]. Nonetheless, over the years there are also appreciations of the definition, including by a number of scholars who chafed and scoffed at the generic definition, but who have since written appreciatively that it is inspired by humanism and caring for human life ([8], p. 163). ${ }^{5}$

In his excellent volume, Genocide Since 1945 [9], Philip Spencer, who was the director of a Joint Program in Human Rights and Genocide Studies in Kingston University, U.K., and in Germany and Italy, also concludes that recent legal rulings infer intent from outcome and do not stand on proving intent to begin with. He notes realistically that [10] "the organizers of genocide have usually been clever enough not to leave evidence if they could avoid it"; and at the same time clarifies that "genocide can be intended even if it does not, in the end, take place." Spencer concludes: "The concept of genocide,

3 It may be of interest to genocide scholars that this was originally the talk that I gave at the "First Raphael Lemkin Seminar on Genocide" at Yale University in February 1991, that was referred to in Reference [1]. The symbolism of honoring the heroic founder of genocide studies, Raphael Lemkin, as well as the meaning of holding a seminar at the prestigious law school and university at which Lemkin taught when he first came to the U.S. touched me so deeply that, with my wife's agreement, I flew from Israel to the U.S. despite the fact that at the time we were in the throes of the Gulf War and missiles were being fired daily on Israel. Only Israel's national airline, $\mathrm{El} \mathrm{Al}$, was flying at the time, and the flights to and from the U.S. also were emotionally charged with an extra sense of danger. But I felt the Symposium marked a breakthrough event in the development of genocide scholarship. Includes a section, "A Proposed Definitional Matrix for Crimes of Genocide" ([1], pp. 7-9).

4 The first proposal for differentiating between first, second or third degree genocide was made by Ward Churchill in 1986 [5] Subsequently, without my knowing of Churchill's paper I proposed the same in my presentation to the Raphael Lemkin Seminar at Yale University Law School ([1], pp. 64-94).

5 "It is time to match Feinian rigour with a more Charnyian range. In short, if we are to tackle genocide's root causes-as scholars and human beings - we are going to have to struggle and campaign for prevention in terms of a much more holistic antidote than we have so far dared to contemplate ... While I do not accept Israel Charny's definitional ultra-inclusivism in matters of genocide, I recognize that there is an underlying humanitarian principle in his work which is in need of scholarly recognition and development."-Mark Levene [8]. 
however slippery, captures both intent and outcome, planning and execution. Above all, it identifies a threat to humanity on an existential scale." 6 Spencer further evaluates the generic definition as follows:

"The one-sidedness of genocide is a central issue for another pioneer, Israel Charny, who fought hard to raise the question of genocide at a time when it was not seen by many as a major problem. His acute awareness of the vulnerability of victims lies at the heart of his own redefinition of genocide... Charny's emphasis in this definition on the weakness and vulnerability of victim groups is very important, particularly when it comes to thinking about what is to be done to help victims." ([9], pp. 21, 27).

\section{The Knowledge That Even Data Collection Is Influenced by a Researcher's Subjectivity}

It is an axiom in the philosophy of science that virtually all acts of assembly of information by scientists are influenced by the guiding concepts in the scientist's mind and are influenced by the very techniques of observation and measurement employed by the scientist. An easy example in the world of psychiatry is when a researcher-practitioner is enthusiastic about proposing a new treatment method; the initial results of such treatment by the same researcher, or by the circle of professionals who are influenced or devoted to him, will likely be far better than will prove to be the case in the future of more routine employment of the treatment. An extremely well-known statement of the dilemma is embodied in the profound crisis that was set off by Heisenberg's Principle of Uncertainty or Indeterminacy in the early 20th century (the more precisely the position of a particle is determined, the less precise can be measurements of its momentum, and vice versa).

In the field of genocide studies there has been considerable disregard for knowledge of the principle that each researcher is playing a significant part even in assembling the information of an event of mass killing or genocide, and certainly when it comes to choosing the identification or category that is given to the event-beginning with the choice of calling it genocide or not.

Thus, consider the following examples.

\subsection{How Many Victims Were Killed?}

Understandably, a researcher who belongs to the same group as the victims may report higher numbers of victims as an unconscious expression of personal tragedy and protest, and sometimes as a conscious strategy of a group to present their losses in the most catastrophic way possible.

\subsection{Which Victim Group Was Targeted?}

A researcher who is committed to a definition of genocide only as an intentional act and/or as an intentional campaign to wipe out all members of a target group may easily ignore less intentional killings of millions of people, such as Mao's virtually indiscriminate killing in his ruthless campaigns of the Great Leap Forward and in the Cultural Revolution in which he killed millions of Chinese citizens who were previously undefined as belonging to any identifiable group; or Pol Pot's murder of a third of the Cambodian population with only small numbers of them identifiable as members of defined target groups (the Buddhist priesthood, and the Muslim Cham people).

\subsection{What Were the Means of Committing the Genocide?}

It is a moot point that full-blown deniers of a genocide are out to warp the facts of the event in many different ways including denials of various means of execution such as the gas chambers of the Holocaust. But even well intentioned and scientifically grounded researchers are known to miss, ignore, and trivialize means of genocide that for one reason or another are not important to them, e.g.,

6 In my opinion this statement by Philip Spencer in Genocide Since 1945 [9] is the simplest and most comprehensive definition of genocide and identifies all of the components that go into evaluations and does not get stuck in any individual component. 
male researchers who do not report rape as a major weapon in a genocidal event, or researchers who are more partial to the use of military force who do not identify saturation bombing or other crimes of disproportionality as crimes against humanity or genocidal acts in the course of a legitimate war.

Paradoxically, the philosophy of science has generated a further insight that the more aware a researcher is and holds himself/herself to knowing about their biases (which everyone has), the more likely it will be that the researcher will assemble more objective information. It is an intriguing dialectic: The more you know that you may not be able to know (because you think you know it all before you start), the more you may indeed be able to know and learn in an unbiased way.

The field of genocide studies has been hugely characterized by little to no awareness or humility about the presentation of information, and certainly about the judgments of significance made by different researchers. The present tool is intended both to provide a more systematic framework and sequence for assembling the factual data about the many different aspects of a genocidal event, and a more systematic framework for making judgments about the classification of the event, while the researcher makes himself/herself aware that it is he/she who is seeing and interpreting the events to the best of their ability, but nonetheless subjectively, and not that there are absolute truths and definitions.

\section{Replacing Definitionalism with Solid, Factual Data Collection}

If we return to basic principles of the scientific method, and concentrate firstly on assembling all the known concrete FACTS of an event of genocide, we will be fulfilling a basic principle of science about getting verifiable information, and setting a far better stage for the kinds of evaluative and definitional concepts that we want to attach to these facts-and that these evaluations can be done well only after a database has been assembled.

This approach frees us from our wasteful pursuits of absolute definitions and the accompanying power battles that have eaten away at so much vitality of our profession of genocide scholarship. Most important, this approach redirects us and our research staffs and students to good basic science.

\section{Part 1 of the Worksheet}

The Worksheet invites the following gathering of data.

\subsection{Genocidal Intention (Objective)}

First, much like describing a disease process clearly in medicine, we track the genocidal event in all of its aspects and signs and twists and turns. Intentionality is included in this assembly of data. We certainly want to know what degree of intentionality is seen in the process of bringing about murders of the designated victims, and whether the intent was to exterminate a total people or to kill a significant number of a designated group (per the Genocide Convention, "in whole or in part"); but also whether the killing culminated in a definite outcome of masses of dead bodies but was done without focused intentionality towards a specific identity group —e.g., a government indiscriminately killing civilians in an effort to keep its power as has been one aspect of the rampant killing in Syria these years [11]. ${ }^{7}$

The Worksheet seeks to identify a wide variety of possibilities with regard to the objective of a genocide, including actual murders of a designated ethnic, national or religious group in what is

7 By now there are thousands of news reports. See a New York Times report from as early as 2012 by an unnamed employee of the New York Times in Syria and Damian Cave, 27 August 2012 [11]. See [12]. Genocide Alert also issued an emergency alert for Syria. GPN Genocide Prevention Now called Syria an "Incremental Genocide" and tracked the mounting figures from issue to issue. Nonetheless, amazingly here too, in the first years of the Syrian genocidal horror, otherwise fine scholars were embroiled in disputes as to whether a definition of "genocide" was called for, or was it a plain old "revolution" or "civil war" as if in these conditions mass killings a priori define a lesser crime than genocide. One prominent leader in the field denied emphatically on the listserv of the International Association for Genocide Scholars that genocide was unfolding while adding the only real danger of genocide in the Middle East was from Israel (!). 
known as ethnic cleansing $[13,14]^{8}$; or genocide as a result of abuse of the human environment via ecological destruction, or via disastrous neglect or failure to meet engineering requirements for safety, e.g., the Chernobyl nuclear plant, or the deaths of civilians in floods in China as a result of massive rerouting of a natural water system (Section "Genocide as a Result of Ecological Destruction and Abuse" in Chapter "Toward a Generic Definition of Genocide" ([1], p. 65)).

This section of the Worksheet also invites an effort at understanding whether the genocidal event was largely directed by a commanding agency, e.g., a key leader like Hitler, Stalin, Mao, or Pol Pot, or the genocidal event unfolded sequentially through a series of progressive events that expanded to increasingly severe and extensive means of extermination, and then also was fed by an intoxication of violence in an escalating progression to greater extremes. Note the same genocidal event can also be identified as both of the above-both commanded by a central agency and spurred by a progression that expanded and worsened from stage to stage. Thus, for many years, and to a lesser extent there are some continuations today, there was an intense dispute between understanding the Holocaust as an intentionalist versus functionalist process. Many scholars progressed to the conception that it was both commanded by Hitler and his senior cohorts like Eichmann, but also characterized by a progressive unfolding from stage to stage to climactic procedures that were not conceived or planned originally by Hitler, like the gas chambers and crematoria, and endless variations like the forced death marches that were carried out even as Germany was collapsing decisively [15].

\subsection{Targeted Victim Group}

The Worksheet records the identity of the targeted victim group, and whether the definition of the intended victim is along lines of racial identity, religious identity, ethnic identity, political affiliation, gender, sexual preference, membership in whatever collective group, combinations of categories, or whatever definition. Note that at all times the Worksheet allows for entering new categories and sub-categories that express most clearly the data as they become available to us. Thus, if genocidal killers choose mentally defective or physically defective people or plain intellectual-looking people with eyeglasses for extermination, categories for this information are formulated and entered.

\subsection{Means of Genocide}

The Worksheet calls for identifying data about the means of genocide. There are so many possible instruments for killing, so many various means of execution-the emphasis is on the outcome-all of which share the same terrible generic outcome of the deaths of many unarmed people.

Differences between various means of execution have many implications in their own right, including the comparative "efficiency" of the means of killing, and in respect of our knowledge and sensitivity to the different kinds of terror, pain and suffering that the victims underwent. Thus some of the many alternative means of killing are the following:

- $\quad$ Direct face-to-face execution by hand or other contact weapons, e.g., like hacking and execution by machete in the Rwandan Genocide, or in our time decapitations by ISIS (ISIL).

- Death camps, concentration camps, gulags, labor camps, and prisons.

- Forced marches, forced deportations or "transfer" of populations; induced famine, e.g., the Ukranian Genocide, and according to emerging reports quite possibly today in North Korea.

8 Personally, I very much view ethnic cleansing as one of the many or multiple forms of genocide, and thereby do not at all minimize its deadly significance as genocide. The purpose of identifying the specific subcategory of a genocide is to convey more meaningfully how the specific genocidal mass murder was carried out since there are many different scenarios for committing genocide. Helpless civilians are dead and we have no right to leave them without a name that clearly protests the genocide that killed them. The Worksheet calls first of all for accurate facts. It is only in the second part of the Worksheet that each researcher is to choose conceptual labels, and these are not to affect the assembly of data which are to continue as an event of mass killing continues and as further information becomes available. 
- Medical killing, such as the murderous series of experiments carried out both by Dr. Mengele in the Holocaust, and by Dr. Ishii in the Japanese invasion of Manchuria.

- Plain old' mass killings, but here too the means of killing vary considerably and need to be specified, e.g., the airplanes that crashed into the World Trade Center on 9/11; or in the Holocaust mass graves, and increased efficiency crematoria-which in turn facilitate mass killing; the infamous gas chambers in the Holocaust (there are also reports these years of a gas chamber operating in North Korea); the directly cruel mutilation and killing face to face with machetes in the Rwandan Genocide.

- Bombing of civilians as a means of genocide, whether intended as genocide or resulting from "facts on the ground" of saturation bombing in which huge numbers of civilians are killed-thus see the controversy about whether the Allied bombing of Dresden constituted genocide [16]; or the more recent controversies about Israeli conduct of the Gaza War in 2014 in the face of Hamas' use of civilians and their homes for launching missiles $[17,18] .{ }^{9}$

- The relatively new curse of our time of transnational genocidal terrorism-terrorist attacks with bombs exploding in civilian areas, markets, churches, hospitals, cemeteries, weddings-in effect everywhere; and much of it in a crazy proliferation (all over the world) of suicide bombings where the killers do not try to protect their own lives.

- Looking to dread future possibilities of Weapons of Mass Destruction (WMD)—what may lie ahead in respect of weapons of mass destruction of nuclear, chemical, biologic or other futuristic weapons.

\subsection{Context-Organizing Theme and Inspiration Imagoes}

Data are now gathered specifying the context or organizing theme and inspirational imagoes of the genocidal event being studied, thus, battles for power, superiority and domination, and/or the many battles to cleanse and purify and rid the world of the defiling Other [19,20]:

- Religious Supremacy;

- Ethnocentric Superiority;

- Battles for Ideological Purity, Supremacy or Domination;

- Economic System Superiority;

- Wartime Crimes against Humanity (1) - Genocide in the course of a war that in plain old-fashioned ways is intended to expand or dominate-and thereby is generally defined in the concepts of the Catholic philosopher, Thomas Aquinas, as an Unjust War;

- Wartime Crimes against Humanity (2) - Genocidal killing in the course of what is defined as a Just War of legitimate self-defense, where the people fighting for their lives go on to massacre enemy civilians in whatever number of genocidal events-thus, Israel's War of Independence was clearly fought in self-defense against intended destruction of its people, but there were also several callous genocidal massacres of civilians and several bursts of formulations of genocidal policy in a number of areas and events [21-23];10

- Genocidal Terrorism;

9 The NGO Monitor (29 June 2015) advances a strong counter thesis by military/legal and Middle East experts. In the words of Major-General Mike Jones, Former Chief of Staff, U.S. Central Command: “While it is positive that the UN's Gaza report acknowledged that all combatants are required to abide by the law, and that Hamas' and other groups' indiscriminate rocket fire at Israel was unlawful, it is disappointing that the report fails to condemn these groups for unlawfully failing to distinguish themselves as combatants, as well as purposefully co-locating amongst civilians, knowingly placing them at risk, with absolutely no military necessity to do so." [18].

10 There have been people, including prominent genocide scholars, who have charged the newly founded State of Israel with genocide for killing Arabs during the War of Independence. There is no doubt about a number of such events-thus see the works of Benny Morris [21-23]. The question is how to interpret these events-inexcusable but common crimes in the course of war, or a basic indictment of Zionism and Israel. Thus see the debate that erupted with Martin Shaw of Roehampton University in London in the report by Beckerman, Gal [25]. 
- Genocidal Killings that Accompany Colonization;

- Globalization-Genocidal acts resulting from relentless exploitation of resources and major industrial development at the expense of the lives of a local population;

- Consolidation of Power "Ecological Genocide" - large-scale manslaughter by ignoring and overriding safety concerns;

- Revolution, Revenge and Attribution-the delight of revenge against people who in the past committed genocide against one's people and therefore "deserve retribution"; similarly executions of "counterrevolutionaries" and "enemies of the state": harsh murderous campaigns sponsored by a governing regime against people in its own society who are identified, rightly or wrongly, as enemies of the state, and a passion of genocidal persecution expands against them; or genocide that is committed "mutually" back and forth between two perpetrators; as well as genocide of a current perpetrator by a victim group [24];11

- Youth Bulge-It has been pointed out by any number of scholars that there is an increasing bulge of a population of unemployed youth and that this is a prime population for recruiting killers [26];

- Utopianism - a dedicated effort at a better society can turn into a bloodbath against critics and non-believers. Even well-intending humanists have been known to go down this road $[27,28]^{12}$

- Genocidal Killing for the Sake of Killing - there are still other existing or emergent themes and inspirations for genocide. Is it possible the killing impulse is instinctive or a natural substrate in the human mind? Much genocidal killing clearly manifests as "killing for killing's sake." The desire and readiness to destroy other living beings is resonant within human beings and may be one of our instinctive systems of thinking and behavior in the basic machinery with which we humans are endowed [29]. ${ }^{13}$

Nonetheless, there is evidence that the killer instinct can be sublimated to a use of power in self-defense and constructive uses of aggression for building life and not for violence and destruction. Not to kill others can be a positive goal of individuals and of a culture that fight against violence [30-32].

\subsection{Identity of Perpetrator}

Data entering continues with identification of who is the perpetrator executing the genocide. In a great number of cases to date it is national governments who are the perpetrators, but there are also a substantial number of situations where others such as the church—see for example the Crusades; or a political party - see a revolutionary party in Columbia in South America; or often enough a revolutionary political movement that grows in power to become the prevailing government-such as was the case in Communist Russia or in Communist China; today a prevailing source of genocide is transnational genocidal terrorism - what seemed like isolated incidents a few years ago are taking on a dimension of an "Ebola epidemic of terrorism."

There are also other "actors" who are to be identified as perpetrators, including a present or past victim people who assert themselves in genocidal retaliation against their genocider; a military, para-military or "special force" that executes genocidal murders (often enough on behalf of a government-such as in the disappearances in Argentina); and even the people themselves can be the immediate perpetrators of genocide, such as in rioting crowds, lynches, and bloodthirsty public trials of "enemies."

11 Nicholas Robins was perhaps the first scholar to conceptualize forthrightly the idea that a people who have been victims of a genocide can themselves become the perpetrating genociders.

12 The shocking almost unbelievable example of utopian thinking - and an explicit call to kill those who stand in the way of the better society-was discovered posthumously in the writings of no less than Abraham Maslow, the beloved founder of humanistic psychology!

13 Thomas Friedman [23] explains evil in a "comic book type conversation" between Batman and his helper. In a brilliant op-ed in the New York Times, Friedman created a fictional parable where the archetypal fictional hero Batman is discussing the source and motivation of evil. "He thought it was good sport. Because some men aren't looking for anything logical like money. They can't be bought, bullied, reasoned or negotiated with. Some men just want to watch the world burn." 
The subject of who executes a genocidal event broadens even further when in addition to identifying the major perpetrators-where we also look for the "architects" and the "executors," we look for accomplices and bystanders, and then to others who give assistance to the execution of the genocide. Individuals, institutions and organizations all play these roles. Any number of societal institutions need to be looked at for those who gave a significant form of assistance to a policy of executions and their implementation in their roles as accomplices or bystanders.

The researcher first fills in the Chart as to the identity of the agent-referring to the full array of parties that are involved in executing a genocide, and then specifies their roles in same-perpetrators, accomplices or bystanders. When looking at the responsible actors or agents who execute the genocide, these can represent any of a large range of identities-a leader, a major perpetrator, a government, political party, church, revolutionaries, terrorists, a people who themselves are the victims of an ongoing genocide and retaliate in kind, a people who were victims in the past and are now retaliating against their victimizers, the military or paramilitary or police or "special forces", or the people as a crowd or collective that erupts in genocidal pogroms or systematic programs of killing. The same is true of the other roles of people who bring about or facilitate a genocide. Accomplices are also to be identified according to the identity of the actor. So can bystanders. Prolific genocide scholar, Samuel Totten, who in addition to his scholarship has braved a remarkably courageous activism on the ground in dangerous Sudan, emphasizes that bystanders are not only within a state/region but "to a much greater extent are those bystanders outside the region who have the power to speak up without the fear of retaliation by the perpetrators and fail to do so." [33].

A few examples: What role did the legal establishment in Germany play in enabling and legitimizing the Nazi regime? What role did the churches play in enabling and even encouraging the Holocaust? Similarly, what roles did churches play in the Rwandan Genocide-a famous example is that of the pastor who ordered bulldozing the church to which he had sent thousands of people to seek safety $[34,35] .{ }^{14}$

What roles did the medical professions play in the Holocaust? Before the Holocaust doctors and nurses engaged in a campaign to "euthanize" the mentally deficient and mentally ill children [36-39]. In the Holocaust the doctors in particular continued their destructive roles as physicians in "selections" and in bringing the gas, defined as medicine, to the crematoria; and more.

Where do educational institutions figure in enabling the event? What about the diplomats of a killing nation? Do any have possibilities of rescuing victims? ${ }^{15}$

What roles did communication and media play in campaigns "advertising" and "hypnotizing" national and other audiences to internalize imagoes of given target peoples as "germs," "bacteria," "filth," or other sources of potential destruction to their host? Thus, the extraordinary hypnotic public pageants and assemblies of the Nazis, or the tragically brilliant radio campaigns calling on the people to prepare to exterminate the "cockroaches"—-the Tutsi in Rwanda [41].

\subsection{Outcome}

The great researcher R. J. Rummel has been the outstanding demographer of genocide and has given us estimates of the tolls of genocides, including his unbelievable but data-grounded estimates of 54 million victims of genocide in the USSR under Stalin, and 36 million victims in China under Mao,

14 Athanase Seromba is a Rwandan priest who was found guilty of aiding and abetting genocide and crimes against humanity committed in the Rwandan genocide. Seromba, a priest of a Catholic parish at Nyange. He was charged with the deaths of around 2000 Tutsis who took refuge in his parish church. Seromba surrendered himself to the International Criminal Tribunal for Rwanda (ICTR) on 6 February 2002.

15 A promising program for reaching the mid-level diplomats of many countries was created by the late Fred Schwarz under a rubric of an Auschwitz Institute for Peace and Reconciliation [40]. Diplomats are invited to gather at the Institute's site immediately adjacent to Auschwitz-Birkenau (!) where they participate in a several day seminar aiming at heightening their awareness that they may be able to save human lives if they recognize persecutory genocidal processes in time and make good moral choices about their roles. 
and an estimated conservative total of no less than 260 million dead by genocide in most of the last century [42-48]. ${ }^{16}$

A second frame for viewing the toll of a genocide is to look at what percentage of the population designated as intended victims has been murdered - the Herero in South Africa were virtually totally exterminated by the Germans at the beginning of the twentieth century; in Cambodia the two million victims of the Khmer Rouge constituted one-third of the total population; in the Holocaust half of the Jewish population in the world was destroyed.

Another summarizing perspective comes from the data of the length of time during which the extermination was carried out. Who can forget the unbelievable killings by Rwandans of one another to the extent of 800,000 victims in no more than approximately 100 days!? For those of us like the great scholar Leo Kuper $[49,50]$ who view the nuclear bombings of Hiroshima and Nagasaki as genocidal events, nuclear genocide occurs first in a devastating flash but then follow agonizing hours and days for many more who die, and then long years of illness and disability, including defective births and the suffering and deaths of many others.

\subsection{Responses to the Genocide}

In our individual lives, there are probably very few people who have not asked themselves what they would have done and what they will do in the event of their being caught up in a genocide as designated victims. The tragic fate of the majority is that they are trapped and led "like sheep to slaughter", and have few opportunities for resistance and rarely inspire and generate resistance. However, there is still a sizable and unforgettable group of people who do resist being victims in a genocide and that is something also to be noted in the Chart. In the Holocaust, for example, there are famous revolts and escapes in Treblinka, Sobibor and the Warsaw Ghetto [51-59].

A no less large question is: what are the responses of people and governments who are not slated to be victims? The Chart provides options for recording intervention, "righteous rescuers," opposition-active fighting back against the genocide, indifference, and allowance-or a failure to respond to the genocide taking place. The data are recorded both for people and agencies (e.g., the church) who live alongside the victim people-say inside the same country, and people, agencies (e.g., the International Red Cross) and countries who are outside the arena of the genocide but can take action that will influence its progression (see the concept of $R 2 P$ or Responsibility to Protect [60-62]). ${ }^{17}$

In the quite dismal history of the human race so far, there are very few instances where countries or groups of countries or agencies of international government have actually gone in to prevent a genocide. ${ }^{18}$ What stand out more than the meager number of successes are a good number of situations in which there was a stark failure to intervene. Several of these have turned into notorious chapters in human history. Thus, the failure of the Allies in WWII to give any real assistance to the victims of the Nazis in the death camps-such as bombing the tracks to Auschwitz [65], or even the abject refusal of

16 R. J. Rummel passed away in 2014. He is considered by many genocide scholars to have developed the outstanding empirical research of genocide to date.

17 In 2006, the UN Security Council passed a landmark resolution obligating governments to protect human life (UN Security Council Resolution 1674). This major development known as the "Responsibility to Protect" or $R 2 P$ was a legislative initiative spearheaded by former Australian Foreign Minister Gareth Evans working alongside Mohamed Sahnoun, a Muslim who was a Special Advisor to the Director-General of the United Nations. Kofi Anan, the former Secretary-General of the UN, and the current UN Secretary-General Ban Ki Moon also joined the initiative as staunch supporters. See [63,64].The resolution is revolutionary because the long prevailing principle dominating international law negates the rights of states to interfere with any decisions of other sovereign states. The meaning of $R 2 P$ is that the principle of state sovereignty is no longer absolute, but regrettably notwithstanding considerable intellectual excitement about the new concept, there is still little evidence of its application in the realpolitik of life, and some observers offer the opinion that the concept will fade away.

18 NATO's intervention in Kosovo in 1999 is considered by many a transformational event which showed that genocide could be prevented. At this writing an international coalition led by the U.S. was created as a military deterrent to the fundamentalist Muslim ISIS, a group whose avowed intention is to create an extended "Caliphate" state that has been rampant with genocidal actions in areas it conquered. 
the United States (and others) to allow a shipload of refugees (the St. Louis) who had succeeded in escaping to disembark on their shores until the boat was forced to head back into Nazi territory and most people died [66]. Thus, the failures of U.N. troops in the Rwandan Genocide in 1994-here the failure centers on the refusal of the U.N. in New York to send the additional troops that U.N. General Dallaire in Rwanda requested, let alone there are serious claims that the French government armed and trained the Hutu Interahamwe who were primarily responsible for the killing. A year later in 1995, another devastating example of the failure of the U.N. took place when the U.N. force of Dutch soldiers, who at first promised Bosnian Muslims refuge, literally turned them over to the Serbs who murdered more than 8000 in a massacre that many called the worst genocidal massacre since WWII.

There are other remarkable instances both of groups and of individuals who take on roles of assisting the victims and/or contribute to the prevention of the genocide. Examples on the level of groups and institutions include diplomatic officials of countries who have contributed passports for the escapes of many intended victims; towns in which the collectivity of residents cooperated in hiding many victims; and churches that fulfilled what many of us believe is the true mission of a religious institution and provided safety for escaping victims. Moreover, of course there are any number of heroic individuals who have saved others, either as a group-see the story of Oskar Shindler saving as many people as he could take in as workers in his plant, or heroic individuals who literally risk their lives taking in victims and giving them shelter. Israel designates and honors people who saved Jews in the Holocaust as "Righteous Gentiles" and the word "righteous" is being picked up somewhat with respect to other peoples in other genocides. Recently there has been more interest shown by scholars and institutions into other cases of genocide where members of the enemy people saved victims, e.g., Turks/Muslims who rescued Armenians/Christians in the Armenian Genocide. [67]. ${ }^{19}$ Thus, "Gariwo, the Forest of the Righteous" is an organization headquartered in Milan, Italy that sponsors gardens of the righteous - thus far gardens are in Italy, Rwanda, Bosnia and Armenia-and has been lobbying the European Parliament for the establishment of a "European Day of Remembrance for the Righteous [68]" (sadly, the chairman of Gariwo conveys that the director of Israel's Yad Vashem refused to consider the inclusion of righteous people from other genocides [69]).

\subsection{Other Important Characteristics of the Genocidal Event}

Aside from the guiding principle of this Worksheet that invites each scholar and researcher to correct, modify, revise and augment any category of data, Row 8 in the Worksheet specifically calls for focusing on any other important characteristic of a given genocidal event that a researcher sees fit to identify, e.g., how common it was in Rwanda for neighbors and even members of a single family to be the executioners of neighbors and relatives, or the ways in which local populations assembled during the Cultural Revolution in China to rule on the fates of fellow citizens and neighbors [70]. Altogether, the data cells create a picture of the unique aspects that are to be found in each genocidal event.

19 Yair Auron of the Open University of Israel has been researching the subject of righteous Muslims. In his forthcoming book he deals with a Circassian-Muslim village in the Caucasus Mountains in 1942 where the villagers saved 32 young children in the Nazi siege of Leningrad [65]. Auron also reports that he has been to Rwanda to interview Hutu-Muslims who saved Tutsis, both Muslim and not Muslim alike. He adds that he is now gathering material about Turks who saved Armenians during the Armenian Genocide. He is also studying the cases of Palestinians who saved Jews during the Palestinian-Israeli conflict, as well as cases where Jews saved Palestinians. Auron also reports that in the village in which he lives in Israel, which is named "Oasis of Peace" and is the only joint Palestinian-Jewish community in Israel, they have recently opened a "Garden of the Righteous Worldwide." 


\section{Part 2 of the Worksheet}

\subsection{Value Judgments of Whether an Event Is Genocide or Another Related Crime}

Having assembled the factual data about an event of genocide, the Worksheet invites each researcher to proceed to the "beloved game" of assigning a definition of the category to which the event belongs.

There are two axes of judgment. The first is an intellectual designation and follows historical and social science terms and classifications. The second judgment is to choose the correct legal definition of a given event under whatever the legal system in which the event is to be judged. Generally, this will be international law, but in any given case it can be the specific legal code of a given country, or both international and local laws, and the researcher must clearly identify the legal system(s) being used. As of today, the legal situation is fluid and immature but clearly developing, with a growing accumulation of judgments in so short a number of years far beyond what earlier genocide researchers dared to expect.

A word of caution: Just because a legal verdict is rendered, it is not necessarily truth. Legal judgments of genocide, like judgments everywhere in life, include bizarre outcomes such as were seen in the ruling of the International Court of Justice in the case brought by Bosnia against Serbia about the genocidal massacre at Srebrenica, where the court ruled first of all that the event indeed constituted genocide, but bizarrely failed to identify Serbia as the perpetrator of the genocide $[71,72] .{ }^{20}$

All of the chaos and nastiness that have been in the field of genocide studies about defining an event of mass murder is cordially invited to come forth now, but this time not in a combative context so much as in an invited act of judgment by each scholar, where it is agreed and clear that the judgment in no way is to affect the accumulation of factual data that has been completed up until now nor further data that will be added in the future.

In metaphors of medical practice, the "doctors" have examined the patient and have concluded recording the history and complaints and symptoms, and now the "doctors" are invited to offer their diagnoses and choices of the category or categories to which the genocidal event is to be referred.

Making judgments is to be clearly differentiated from assembling facts. The earlier work on the first part of the Worksheet aims at contributing to consensual factual information about what happened. Now each researcher formulates his/her own judgments_opinions, choices_about how to define and classify the event. There is an a priori understanding that the classifications selected among alternatives are the choices of different researchers and not sacrosanct facts of absolute knowledge.

Of course, in some cases the known facts will drive most researchers towards a specific classification-if the perpetrator fully intended to kill a victim people, it is inevitably an Intentional Genocide and one expects most researchers to say so. But in many cases the final classification is more a judgment of the severity, meaning and significance of the event than the facts in themselves disclose.

As the field progresses, there will certainly be greater significance to such judgments of ongoing events by researchers, and especially as to what actions should be taken to stop an ongoing genocide. Such recommendations for interventions are not included in the present Worksheet at this time, nor have we prepared separate data sheets for past genocidal events where in a sense all or most of the facts are available, and events currently in progress where characteristically the information is often more fluid and contradictory.

20 On 26 February 2007, the International Court of Justice issued its judgment in Bosnia and Herzegovina v. Serbia and Montenegro. The case was the first time a country sued another country for a breach of the U.N. Genocide Convention. The judgment was complex and lengthy and in the opinion of many of us absurd. The court concluded that Serbia had violated its obligations under the Convention by failing to prevent the genocide of over 7000 Bosnian Muslims at Srebrenica in July 1995. At the same time the Court ruled that Serbia was not the perpetrator directly responsible for the genocide. 


\subsection{Identifying the Biases of Researchers}

After entering the name of the researcher and/or research group assembling the data, each researcher is asked to identify personal characteristics of age, gender, ethnicity/religion, and geographical location. Each of these may point in the direction of possible biases that are characteristic of different population groups. Most important, scholars and researchers are asked to spell out the basic definition of genocide they have personally adopted, as well as any other relevant value positions that are guiding their scholarly work. Thus, a researcher who is committed to valuation of the Holocaust as a unique event that goes beyond other cases of genocides would spell out this guiding conviction that obviously will enter into the choices he makes in defining Axis One and Axis Two classifications of genocide. The Worksheet itself provides room for a brief notation, but it is suggested that researchers may want to add an additional page on which they spell out their basic positions more fully.

Each completed Worksheet is a statement of a given researcher or research group. Moreover, it is clear that the data-gathering in each case is likely to be influenced by the demographic characteristics of the researchers and especially by whatever core concept of genocide they have adopted.

Again it is emphasized that the format of the Worksheet presently is to facilitate an assembly of wide-ranging comprehensive information about a genocidal event. It is suggested that because so many researchers in the past have rushed to qualify an event as genocide or not, and in many cases the concept of genocide has been treated as a single global entity without sufficient attention to the various subcategories which differ quite a lot from one another, the data gathering process too often has been attenuated and too many aspects of a genocidal event have been left unexamined. At the same time, the present Worksheet as it is presently designed is not intended to create a formal, scientifically validated, and reliable summary, although the format will lend itself to researchers who will wish to do comparative studies of the data gathering and categorizations of different researchers.

It has been further emphasized that the act of judging and categorizing events of mass killing is intentionally deferred to follow data gathering so as to better represent the principle that categorization flow from and be based on actual data more than on biases of any given identity groups and its biases.

Clearly, the recording of history, and the work of scholars and researchers, have always been profoundly influenced by the personal and cultural qualities of the scholars. Thus, national and ethnic identities play powerful roles: The mass killings in Cyprus tend to be reported and analyzed differently by Greek and Turkish scholars; Zionist Jews and non-Zionist Jews will see differently how central was the Jewish identity of victims of the Nazis; native people will evaluate differently the genocidal nature of the mass killings of native peoples or forced abductions of native children.

It is basically always true in science that a scholar or researcher does have some point of view with respect to the controversial or ambiguous or unknown knowledge in the field in which they are working. Identifying personal positions and biases, and taking responsibility for the role they play in one's judgments, is one proven method in science for trying to reduce the role of blind biases and their impositions on the assembly of information. Thus it will be appropriate here to note that the bias of the author of this Worksheet is for a "generic definition of genocide" with multiple sub-classifications of the specific type of genocide.

See also professional criteria that have been proposed for publishing statements accusing policies and actions of being genocidal [73].

\section{Conclusions}

The collection of data about an event of mass killing needs to be done as carefully and objectively as possible without any connection to the judgments that are to be made as to whether the event constituted a genocidal act. The methodological format presented here calls both for a wide-ranging assembly of data and for judgments about the most appropriate definitions or classifications of the event. 
Moreover, the present Worksheet places before the scholars' eyes various contexts of identities and basic philosophies that are likely to play a role in their scholarship and judgment. It is the author's conviction that there are multiple forms of genocide-similar to how common murderers also are classified in different groups and degrees; and that the use of the word "genocide" cannot be restricted to Intentional Genocide-a concept that rightly describes a good number of events such as the Holocaust and Armenian Genocide—but far from all cases of genocidal killing. Throughout, it is emphasized that the proposed model is open to corrections, additions, and revisions by other scholars.

As noted, a major advantage of the Worksheet is that it explicitly defers judgments as to whether any act of mass murder constituted genocide or other alternative and sub-classifications definitions of an event of mass killing - until after considerable information has been recorded "simply" about the facts of what happened in reality. A major purpose of this strategy is to defer-and in the best case scenario to avert- the endless definitional battles as to what is genocide and what is not- that have thoroughly distracted the field of genocide studies as well as many government policy makers.

It should be noted clearly that the Worksheet is not intended to provide a predictive instrument-such as one finds in the Genocide Early Warning System $[74]^{21}$, or Gregory Stanton's Eight Stages of Genocide [78], Barbara Harff's risk assessment reports [79,80], or most extensively in Ulfelder and Valentino [81], and Ulfelder [82]. Such early warning systems are intended to provide defined criteria for purposes of evaluating and predicting the possibility and probability of emerging genocidal events, and these criteria are to be subjected to studies of the reliability of ratings by different observers.

The present Worksheet is designed as a working tool beginning with individual researchers for compiling systematically the available information about the various aspects of a genocidal event that already has occurred. There are no immediate tests of the reliability of judgments. Of course, scholars are recommended to review their findings with one another, but this Worksheet is not intended as a formal instrument for testing statistically the extent of agreement and disagreement between scholars. It is a systematic framework for the early stage of assembling the data that are then to be brought to the knowledge of other scholars and to the time-honored contests of ideas in science.

Of course, the very nature of scientific scholarship is that in time the facts recorded by different observers will be subjected to comparison with one another; and in the case of a research group project, these comparisons will be made in the course of the decisions as to what to record in the Worksheet. Virtually all aspects of an event are subject to differences in the observations of different researchers. A seemingly small but not really trivial example involves the number of victims murdered. The many deniers of the Holocaust [83], Armenian Genocide [84], and various other genocides [85] frequently argue that the number of victims was far less than is generally stipulated as if these lower numbers support minimizing the significance of the event of mass killing. There are even noteworthy differences in specifying who were the victims, where these facts too are subject to a variety of nationalistic/political/ideological biases. Thus, we find outstanding examples of omissions of very significant victims in the narratives and observations provided by major victim groups that, consciously and unconsciously, seek to remove the records of co-victim peoples [86], e.g., in the case of

21 The proposal for a Genocide Early Warning System (GEWS) was originally formulated by Israel Charny and was developed in collaboration with Chanan Rapaport. The first publication, jointly authored, appeared in 1977. Although several pilot studies were run, the GEWS never secured sufficient funding to be activated. However, the theoretical model of GEWS has also been applied to the reconstruction of other genocides including Astourian [75] on the Armenian Genocide, De Champs and De Champs [76] on the genocide in Rwanda in 1994, and Paulino [77] on a threat of genocide in the Dominican Republic.The Genocide Early Warning System was hailed by Willie Brandt of Germany, Pierre Mendes-France of France, and by Roberta Cohen, Human Rights Officer of the US Department of State. It was described in Choice, a library review magazine, as "brilliant," and in the New York Times Book Review as a "noteworthy contribution to thinking about the condition of humanity on the earth"; and it was recognized by a United Nations study on genocide which stated: "Many welcome the establishment of early warning systems for potential genocide situations in order to prevent recurrence of the crime. Intelligent identification of potential cases could be based on the databank of continuously updated information, which might enable remedial, deterrent overt measures to be planned ahead. Reliable information is the essential oxygen for human rights: this could be facilitated by the development of the United Nations satellite communications network." (A United Nations pamphlet that is currently unavailable to us). 
the Holocaust alongside the Jews, the murders of Roma (Gypsies), POW's, homosexuals, Jehovah's Witnesses [87]; and in the case of the Armenian Genocide, the long term denials (which are now showing signs of reduction) by the omission of the accompanying genocides of the Assyrians, Yezidis , and Greeks [88].

The Worksheet in effect calls on genocide scholars to account systematically for a variety of aspects of a genocidal event and to make them the basis for subsequent judgments and policy recommendations. It is both a push towards more complete data gathering and a flexible though comprehensive framework for gathering the facts. ${ }^{22}$

Supplementary Materials: The Worksheet for Describing and Categorizing a Genocidal Event is available online at www.mdpi.com/2076-0760/5/3/31/s1, Part I: Assembling Data about an Event of Mass Killing without reference to categorizing the event, Part II: Judgments: Categorizing a Genocidal Event.

Conflicts of Interest: The author declares no conflict of interest.

\section{Appendix A}

This publication is intended first and foremost to bring researchers a new tool. It is not intended as a comprehensive review of the contributions of the many thinkers in the field of genocide studies. An earlier draft of the Worksheet included identifications of the names of some of the classic contributors to the field next to the major concept they had contributed, e.g., Leo Kuper on "genocidal massacres", or David Scheffer's "atrocity crimes." However, when I sent the paper out for critical review by a number of colleagues, I was flooded with questions and protests in both possible directions of why had I included so and so's name and why had I not included such and such others? The names of all researchers now have been removed from the Worksheet Chart but many are listed below along with a few references to selected concepts. Numbers attached to each concept are the locations of the concept in the Worksheet Chart:

"Intentional Genocide" (1A): United Nations Convention on the Prevention and Punishment of the Crime of Genocide formulated in 1948 [70]; Spencer, Philip [9]

Genocidal Massacre (1B): Kuper, Leo [49]; Markusen, Eric [90]

Crimes against Humanity (1D—see also 9D and 10D): The first prosecution for crimes against humanity took place at the Nuremberg Trials. Sadat, Leila Nadya [91]

Manslaughter-See Genocidal Manslaughter (1D): Churchill, Ward [5]; Charny, Israel W. ([1], pp. 21-22, 64-94) Humanicide (1E): The term humanicide appears for the first time to our knowledge in [92] Drost, Pieter N. in 1959. Drost's book is the earliest work we know of in the English language after the seminal work of Raphael Lemkin [93] and before the first three pioneering works in English in the United States by Horowitz [94], Kuper [49], and Charny [95] that are known to have set the stage for the development of genocide studies. The word humanicide is then used occasionally by a few researchers, e.g., see [96] Sheleff, Leon Shaskolsky. See also a clear article advancing the basic concept of humanicide but does not employ the word: McFarland, Sam; Brown, Derek; and Webb, Matthew [32]

Democide (1E): Rummel, R.J. [44,45,47,49]

Highly Violent Societies (1E): Gerlach, Christian [97]

Mass Killing (1E): Valentino, Benjamin [98]

Ethnic Cleansing (1E): Naimark, Norman N. [14]

22 There are important and complex data systems for predicting genocide and political violence. However, these require systematic coding and more than likely a team of researchers. Thus, Ulfelder, Jay, and Valentino, Benjamin [81]; Ulfelder, Jay [82]; Uppsala Conflict Data Program, at Uppsala University in Sweden records ongoing violent conflicts since the 1970s [89].The present Worksheet is for everyday use, including by individual researchers, to record the known facts of a past or ongoing genocidal event. As far as I can see none of the data sets about political violence are tailored to create a "case history" of a genocidal event. See Ulfelder's essay above in which he bemoans wryly that his almost no one is using his data set on political violence [82]. 
Genocidal Manslaughter (1E): Churchill, Ward [5]; Charny, Israel ([1], pp. 64-94)

Accomplices to Genocide, Conspiracy to Commit Genocide, Facilitating Genocidal Act (1F): Charny, Israel W. (Section "Accomplices to Genocide" in Chapter "Toward a Generic Definition of Genocide" [1], pp. 77, 83-84); Travis, Hannibal [99,100]

Genocide by Attrition (1G): Fein, Helen [101]

Ecological Destruction = Ecocide (1G): Charny, Israel W., (Section "Genocide as a Result of Ecological Destruction and Abuse" in Chapter "Toward a Generic Definition of Genocide" [1], p. 65).

Religious Genocide $(1 \mathrm{H})$ : The concept of genocide on the basis of religious identity is a "given" in the formulation of the concept of genocide as created by Raphael Lemkin [93]. In a sense almost all of the literature of genocide studies refers to religious genocide. Two excellent specific references are the seminal work of Leo Kuper [49] and the comprehensive overview of genocide by Philip Spencer [9] Political Genocide or Politicide (1H): Harff, Barbara, and Gurr, Ted Robert [102]

Ideological $(1 \mathrm{H})$ : This concept too is central to almost all genocide studies. Charny, Israel W. [103]; Kiernan, Ben [104]; Semelin, Jacques [20]

Genocide for Power and Domination $(1 \mathrm{H})$ : Horowitz, Irving Louis [94]

Killing for Killing's Sake and Necrophilia (1I): Fromm, Erich [105]; Friedman, Thomas [29]

Cultural Genocide (1J): This concept appears in the classic work, Axis Rule in Occupied Europe by [93] Raphael Lemkin, and he is generally credited with its prominent inclusion in the [97] United Nations Convention on the Prevention of the Crime of Genocide [106]. However, Lemkin also left a rich legacy of unpublished work (in his archives one finds one after another rejection by publishers who say his work is very interesting but will not have a market!). The first scholar that I know of who devoted himself to retrieving Lemkin's writings was Steven L. Jacobs [107,108]. See also Frieze, Donna-Lee [109]

Gender (2E): Jones, Adam [110]

Enemy Civilians in War (2G): Markusen, Eric, and Kopf, David [16]

Transnational Genocidal Terrorism, and Suicide Bombing (3H): Charny, Israel W. [31]; Dekmajian, R. Hirair [111]

Weapons of Mass Destruction: Nuclear, Biological, Chemical, Other Futuristic Weapons (3I): Santoni, Ronald E. [112]; Lifton, Robert J., and Markusen, Eric [113]; Leslie, John [114]; Rees, Martin [115]; United Nations. Weapons of mass destruction. First Committee 2013 civil society presentations [116]

Rape (3J): Joeden-Forgey, Elisa Von. Gender and Genocide [117]; Smith, Roger W. [118]

Preventing Births (3J): Fournet, Caroline [119]

Planetocide (3J): To the best of my knowledge this concept-which is obviously bread and butter in the burgeoning science fiction of star wars-has been introduced in the formal academic literature by this author in a satire [120]. For a related satire on varying types of genocide, see editorial column by Harut Sassounian in California Courier, 21 April 1988 [121].

Random Terrorism (3J): Charny, Israel W. [31]; Breyer, Daniel [122]; Forsythe, David P. [123]

Dehumanization and Demonization (4A): Charny, Israel W.; Stanton, Gregory [95,103]. The basic reference to a very useful summary of the stages of genocide has been Stanton, Gregory which refers to eight stages of genocide [78]. See also Stanton, Gregory [124]. More recently Stanton [125] (no date given) has elaborated the model into ten stages of genocide

Revolutionaries (5D): Melson, Robert [126]

Crimes against Humanity (1D,9D,10D): This category is seen very differently by different scholars. Some place crimes against humanity as a separate category that is to bear a somewhat lesser degree of responsibility than the categories of "genocide." Others consider crimes against humanity a subset or type of genocide and use the category for massive terror and injury to broad populations. The latter can include actual killing but the killing is done differently than intentional genocidal targeting a specific victim people (so that in some case there can be charges against a perpetrator both of genocide and crimes against humanity). Still other scholars want to get rid of the term genocide altogether and work entirely within the concept of crimes against humanity or with some other concept they propose. 
One sensitive scholar has pointed out that victim peoples inevitably will insist that the event that befell them be known as "genocide" and only as genocide.

For this writer, the critical issue in any and all mass killing of unarmed civilians is that the lives of human beings were terminated, and therefore I advance the concept that all mass killing of unarmed civilians be defined first of all as genocide, and then sub-classified further into meaningful categories or types. In this way the everyday usage of "genocide" is respected and our need to identify and differentiate different types of genocidal mass killing is also fulfilled. Charny, Israel W. [6]

Attempted Genocide (10E): Michael Bazyler, a professor of law, points out that although attempted genocide is indeed "on the books," there has never been any legal action based on it. Personal Communication [127].

\section{References and Notes}

1. Charny, Israel W. “Toward a Generic Definition of Genocide." In Genocide: Conceptual and Historical Dimensions. Edited by George Andreopoulos. Philadelphia: University of Pennsylvania Press, 1994, pp. 64-94. Presented originally at the Raphael Lemkin Symposium at the Yale University Law School on Genocide, February 1991.

2. Gallagher, Adrian M. "A system society and community perspective on genocide." Genocide Studies and Prevention 7 (2012): 166-83. [CrossRef]

3. Apsel, Joyce, and Ersnesto Verdeja, eds. Genocide Matters: Ongoing Issues and Emerging Perspectives. New York: Routledge, 2013.

4. Westermann, Edward B. "Genocide Matters: Ongoing Issues and Emerging Perspectives edited by Joyce Apsel and Ernesto Verdeja (review)." Genocide Studies International 8 (2014): 112-15. [CrossRef]

5. Churchill, Ward. "Genocide: Toward a functional definition." Alternatives 11 (1986): 403-30. [CrossRef]

6. Charny, Israel W. "Classification of a Genocide in Multiple Categories." In Encyclopedia of Genocide. Edited by Israel W. Charny. Associate Editors: Rouben Paul Adalian, Steven L. Jacobs, Eric Markusen, Samuel Totten; Bibliographic Editor: Marc I. Sherman; Managing Editor: Pauline Cooper. Forewords by Archbishop Desmond Tutu and Simon Wiesenthal; Santa Barbara and Oxford: ABC-Clio, 1999, vol. 1 and vol. 2, pp. 3-9. Includes a section, "A Proposed Definitional Matrix for Crimes of Genocide": pp. 7-9.

7. Katz, Steven. The Holocaust in Historical Context. New York: Oxford University Press, 1994, vol. 1.

8. Levene, Mark. "A dissenting voice: or how current assumptions of deterring and preventing genocide may be looking at the problem through the wrong end of the telescope. Part I." Journal of Genocide Research 6 (2004): 153-66. [CrossRef]

9. Spencer, Philip. Genocide since 1945. London and New York: Routledge, 2012.

10. Spencer, Philip. “Intent." In Genocide since 1945. London and New York: Routledge, 2012, pp. 12-13.

11. New York Times. "Rwanda's Unanswered Screams: Still Seeking Justice after the Seromba Trial." Available online: http:/ / www.haguejusticeportal.net/index.php?id=7123 (accessed on 7 November 2010). Written by an unnamed employee of the New York Times in Syria and Damien Cave.

12. The International Association of Genocide Scholars (IAGS). "The Resolution of the International Association of Genocide Scholars on Syria." 5 June 2012. Available online: http://www.genocidescholars.org/ sites/default/files/document $\% 09 \% 5$ Bcurrent-page\%3A1\%5D/documents/IAGS\%20Resolution\%20on $\%$ 20Syria.pdf (accessed on 10 June 2012).

13. Blum, Rony, Gregory H. Stanton, Shira Sagi, and Elihu D. Richter. "Ethnic cleansing bleaches the atrocities of genocide." European Journal of Public Health 18 (2008): 204-9. [CrossRef] [PubMed]

14. Naimark, Norman N. Fires of Hatred: Ethnic Cleansing in Twentieth-Century Europe. Cambridge: Harvard University Press, 2001.

15. Porter, Jack Nusan. "Holocaust Controversies: A Point of View." In Encyclopedia of Genocide. Edited by Israel W. Charny. Forewords by Archbishop Desmond Tutu and Simon Wiesenthal; Santa Barbara and Oxford: ABC-Clio, 1999, pp. 307-13.

16. Markusen, Eric, and David Kopf. The Holocaust and Strategic Bombing: Genocide and Total War in the Twentieth Century. Boulder: Westview Press, 1995.

17. United Nations Human Rights Council. "Human Rights Situation in Palestine and Other Occupied Arab Territories: Report of the Detailed Findings of the Independent Commission of Inquiry Established Pursuant 
to Human Rights Council Resolution S-21/1." June 2015. Available online: http:/ /www.ohchr.org/EN/ NewsEvents/Pages/DisplayNews.aspx?NewsID=16166\&LangID=E (accessed on 4 December 2015).

18. Non-Governmental Organization Monitor (NGO Monitor). “Experts Provide Alternative Voice to UN Gaza Report: Events and Interviews." 29 June 2015. Available online: http://www.ngo-monitor.org/article/ experts_provide_alternative_voice_to_un_gaza_report_events_and_interviews (accessed on 3 July 2015).

19. Cohn, Norman. Europe's Inner Demons: The Demonization of Christians in Medieval Christendom. Chicago: University of Chicago Press, 2001.

20. Semelin, Jacques. Purify and Destroy: The Political Uses of Massacre and Genocide. New York: Columbia University Press, 2009.

21. Morris, Benny. The Birth of the Palestinian Refugee Problem, 1947-1949. Cambridge: Cambridge University Press, 1987.

22. Morris, Benny. The Birth of the Palestinian Refugee Problem Revisited. Cambridge: Cambridge University Press, 2004.

23. Morris, Benny. 1948: A History of the First Arab-Israeli War. New Haven and London: Yale University Press, 2011.

24. Robins, Nicholas A. Genocide and Millennialism in Upper Peru: The Great Rebellion of 1780-1782. Westport: Praeger, 2002.

25. Beckerman, Gal. "Top genocide scholars battle over how to characterize Israel's actions." The Forward, 25 February 2011. Available online: http:/ / forward.com/news/135484/top-genocide-scholars-battle-overhow-to-character/ (accessed on 27 February 2011).

26. Heinsohn, Gunnar. “Babies Win Wars.” Wall Street Journal, 6 March 2006. Available online: http:/ /www.wsj. com/articles/SB114159651882789812 (accessed on 8 March 2006).

27. Chalquist, Craig. "Maslow's Descent: When high peaks cast long shadows." Available online: www. terrapsych.com/maslow.html (accessed on 2 December 2012).

28. Maslow, Abraham Harold. The Journals of A. H. Maslow. Edited by Richard J. Lowry. Monterey: Brooks-Cole, 1979.

29. Friedman, Thomas. "ISIS, Boko Haram, and Batman." International New York Times, 4 October 2014. Available online: http:/ / www.nytimes.com/2014/10/05/opinion/sunday/thomas-l-friedman-isis-boko-haram-andbatman.html?_r=0 (accessed on 16 November 2015).

30. Charny, Israel W. "Which people and genocides matter more? Learning to care about humanity." In Genocide in the Twentieth Century: An Anthology of Oral Histories. Edited by Samuel Totten, William S. Parsons and Israel W. Charny. New York: Garland Publishing, 1995, pp. 535-42. Paperback, revised and expanded, with title change: Century of Genocide: Eyewitness Accounts and Critical Views, 1997, pp. xiii-xix.

31. Charny, Israel W. Fighting Suicide Bombing. New York: Praeger Security International, 2007.

32. McFarland, Sam, Derek Brown, and Matthew Webb. "Identification with all humanity as a moral concept and psychological construct." Current Directions in Psychological Science 22 (2013): 194-98. [CrossRef]

33. Totten, Samuel (University of Arkansas, Fayetteville, AK, USA). Personal communication, 19 February 2014.

34. BBC News. "Priests Get Death Sentence for Rwandan Genocide [a court in Rwanda Sentenced Two Catholic Priests to Death for Their Role in the Genocide of 1994." 19 April 1998. Available online: http://news.bbc.co.uk/2/hi/africa/79987.stm (accessed on 20 April 1998).

35. Venturini, Gabriella. "Rwanda's Unanswered Screams: Still seeking justice after the Seromba trial." The Hague Justice Portal, 28 February 2007. Available online: http://www.haguejusticeportal.net/index.php?id=7123 (accessed on 10 March 2015).

36. Sachs, Shimon. Action T4: Mass Murder of Handicapped in Nazi Germany. Tel Aviv: Papyrus Publishing House, Tel Aviv University (Hebrew), 1985.

37. Proctor, Robert N. Racial Hygiene: Medicine under the Nazis. Cambridge: Harvard University Press, 1988.

38. Sereny, Gitta. Into that Darkness: An Examination of Conscience. New York: Vintage Books, 1983.

39. Fredric Wertham. A Sign for Cain. New York: Macmillan, 1967.

40. "Auschwitz Institute for Peace and Reconciliation." Available online: http:/ /www.auschwitzinstitute.org (accessed on 3 April 2006).

41. Chalk, Frank. "Radio Propaganda and Genocide." MIGS [Montreal Institute for Genocide Studies] Occasional Paper, 1999. Available online: https:/ friendsofevil.wordpress.com/2010/11/02/radio-propaganda-andgenocide/ (accessed on 17 March 2012).

42. Rummel, Rudolph J. Statistics of Democide: Genocide and Mass Murder since 1900. New Brunswick: Transaction Publishers, 1999. 
43. Rummel, Rudolph J. Lethal Politics: Soviet Genocide and Mass Murder since 1917. New Brunswick: Transaction Publishers, 1990.

44. Rummel, Rudolph J. Democide: Nazi Genocide and Mass Murder. New Brunswick: Transaction Publishers, 1991.

45. Rummel, Rudolph J. “The New Concept of Democide." In Encyclopedia of Genocide. Edited by Israel W. Charny. Forewords by Archbishop Desmond Tutu and Simon Wiesenthal. Santa Barbara and Oxford: ABC-Clio, 1999, pp. 18-34.

46. Rummel, Rudolph J. China's Bloody Century: Genocide and Mass Murder since 1900. New Brunswick: Transaction Publishers, 1991.

47. Rummel, Rudolph J. Death by Government. New Brunswick: Transaction Publishers, 1994.

48. Rummel, Rudolph J. Power Kills: Democracy as a Method of Nonviolence. New Brunswick: Transaction Publishers, 1997.

49. Kuper, Leo. Genocide: Its Political Use in the Twentieth Century. London: Penguin Books. New Haven: Yale University Press, 1983.

50. Kuper, Leo. The Prevention of Genocide. New Haven: Yale University Press, 1985.

51. Wiernik, Yankel. A Year in Treblinka: An Inmate Who Escaped Tells the Day-to-Day Facts of One Year of His Torturous Experiences. New York: American Representation of the General Jewish Workers' Union of Poland, 1945.

52. Willenberg, Samuel, and Wladyslaw Bartoszewski. Surviving Treblinka. Edited by Samuel Willenberg and Wladyslaw Bartoszewski. New York: Meridian, 1989.

53. Arad, Yitzhak. Belzec, Sobibor, Treblinka: The Operation Reinhard Death Camps. Indianapolis: Indiana University Press, 1987.

54. Escape from Sobibor, Directed by Jack Gold. Music composed by Georges Delerue. Story by Richard Rashke and Stanislaw Szmajzner. Belgrade: CFS Avala Film, 12 April 1987. Belgrade: CFS Avala Film, 12 April 1987.

55. Rashke, Richard. Escape from Sobibor, 2nd ed. Champaign: University of Illinois Press, 1995.

56. Gutman, Israel. Resistance: The Warsaw Ghetto Uprising. Boston: Mariner Books, 1998.

57. Uprising. Directed by Jon Avnet. Music composed by Maurice Jarre. Story by Jon Avnet and Paul Brickman. Los Angeles: Avnet-Kerner Productions, 2001. Los Angeles: Avnet-Kerner Productions, 2001.

58. Schelvis, Jules. Sobibor: A History of a Nazi Death Camp. Oxford \& New York: Berg, 2007.

59. United States Holocaust Memorial Museum. "The Holocaust: A Learning Site for Students. The Warsaw Ghetto Uprising." Available online: http:/ / www.ushmm.org/outreach/en/article.php?ModuleId=10007745 (accessed on 4 February 2016).

60. Evans, Gareth, and Mohammed Sahnoun. “The Responsibility to Protect." Foreign Affairs, Nov.-Dec. 2002, pp. 99-110.

61. The Economist. “An Idea Whose Time has Come-And Gone.” 25 July 2009. Available online: http:/ / www. economist.com/node/14087788 (accessed on 29 July 2009).

62. Williams, Ian. "Ban Ki Moon and R2P." Foreign Policy in Focus, 3 August 2009.

63. World Health Organization. "World Summit Outcome, Document 15." September 2005. Available online: http:/ / www.un.org/womenwatch/ods/A-RES-60-1-E.pdf (accessed on 25 December 2006).

64. Oxfam America. "Security Council Passes Landmark Resolution-World Has Responsibility to Protect People from Genocide." 28 April 2006. Available online: https:/ /www.oxfamamerica.org/press/securitycouncil-passes-landmark-resolution-on-genocide/ (accessed on 3 March 2010).

65. Neufeld, Michael I., and Michael Berenbaum. The Bombing of Auschwitz: Should the Allies Have Attempted It? Lawrence: University Press of Kansas, 2003.

66. Gordon, Thomas, and Max Morgan-Witts. Voyage of the Damned: A Shocking True Story of Hope, Betrayal, and Nazi Terror. New York: Skyhorse Publishing, 2010.

67. Auron, Yair. "He Who Saves One's Soul": The Story of the Circassian-Muslim Village in the Caucus Who Saved Jewish Children from Leningrad and Its Significances. Tel Aviv: Resling, 2015. (In Hebrew)

68. Radice, Ulianova, and Valentina De Fazio. Gariwo-I Giardini Dei Giusti. Milano: The Gardens of the Righteous, 2014, Available online: http:/ /it.gariwo.net/giardini/ (accessed on 5 November 2014).

69. Gariwo, Gabriele Nissim (The Garden of the Righteous, Milano, Italy). Personal Communication at the International Conference on the Holocaust and Genocide at the Open University of Israel, 2014.

70. Chang, Jung, and Jon Halliday. Mao: The Unknown Story. New York: Knopf, 2005. 
71. Foster Jason Morgan, and Pierre-Olivier Savoie. "World Court Finds Serbia Responsible for Breaches of Genocide Convention, but Not Liable for Committing Genocide." American Society International Law, 2007. Available online: www.asil.org/insights070403.cfm (accessed on 4 December 2012).

72. BBC News. "Serbian president apologises for Srebrenica 'crime'." 25 April 2013. Available online: http://www.bbc.com/news/world-europe-22297089 (accessed on 27 April 2014).

73. Charny, Israel W. "Proposed Checklist of Ethical and Professional Criteria for Publishing Statements Accusing Policies and Actions of being Genocidal (including Crimes against Humanity)." GPN Genocide Prevention Now, 2012. Available online: http://www.ihgjlm.com/wp-content/uploads/2016/01/Proposed-ChecklistEthical-Professional-Criteria.pdf (accessed on 10 June 2016).

74. Charny, Israel W. "Towards a Genocide Early Warning System." In How Can We Commit the Unthinkable?: Genocide, The Human Cancer. Foreword by Elie Wiesel. Boulder: Westview Press, 1982, pp. 283-331.

75. Astourian, Stephan. "The Armenian Genocide: An interpretation." The History Teacher 23 (1990): 111-60. [CrossRef]

76. DeChamps, Elisabeth, and Phillipe DeChamps. "Le Gènocide Rwandais: Deux Ans Après: Le Modelle d'Israel W. Charny." Dialogue 1 (1996): 10-32.

77. Paulino, Edward. "Anti-Haitianism, historical memory, and the potential for genocidal violence in the Dominican Republic." Genocide Studies and Prevention 1 (2006): 265-88. [CrossRef]

78. Stanton, Gregory. "Eight Stages of Genocide. Working Paper (GS 01) of the Yale Program in Genocide Studies." 1998. Available online: http://www.genocidewatch.org/TheEightStagesofGenocidebyGregoryHStanton.htm (accessed on 24 November 2010).

79. Harff, Barbara. "Risk assessments." Genocide Prevention Advisory Network. Available online: http://www. gpanet.org/content/barbara-harffs-risk-assessments (accessed on 16 March 2012).

80. Harff, Barbara, and Ted Robert Gurr. "Systematic early warning of humanitarian emergencies." Journal of Peace Research 35 (1998): 551-79. [CrossRef]

81. Ulfelder, Jay, and Benjamin Valentino. "Assessing Risks of State-Sponsored Mass Killing." 2008. Available online: http:// papers.ssrn.com/sol3/papers.cfm?abstract_id=1703426 (accessed on 21 June 2014).

82. Ulfelder, Jay. "A Useful Data Set on Political Violence that Almost No One Is Using." 10 June 2014. Available online: https:/ / dartthrowingchimp.wordpress.com/2014/06/10/a-useful-data-set-on-political-violencethat-almost-no-one-is-using/ (accessed on 4 January 2016).

83. Lipstadt, Deborah. Denying the Holocaust: The Growing Assault on Truth and Memory. New York: Simon and Schuster, 2012.

84. Smith, Roger W., Eric Markusen, and Robert Jay Lifton. "Professional ethics and the denial of Armenian Genocide." Holocaust and Genocide Studies 9 (1995): 1-22. [CrossRef]

85. Charny, Israel W. "A classification of denials of the Holocaust and other genocides." Journal of Genocide Research 5 (2003): 11-34. [CrossRef]

86. Charny, Israel W. “The integrity and courage to recognize all the victims of a genocide: Naming all other victims alongside one's own people, and where necessary even acknowledging violence done by our own victim people, without defining oneself as a traitor." In Genocide Against the Ottoman Greeks: Facts and Interpretation. Edited by Tessa Hoffman, Matthias Bjørnlund and Vasifleios Meichanetsidis. Athens and New York: Aristide D. Caratzas Publisher, 2010, pp. 21-38.

87. Berenbaum, Michael. A Mosaic of Victims: Non-Jews Persecuted and Murdered by the Nazis. New York: NYU Press, 1992.

88. Genocide Prevention Now (GPN). “Armenian Genocide and Co-Victims: Assyrians, Yezidis, Greeks.” 2011. Available online: http:/ /genocidepreventionnow.org/Home/GPNISSUES/SpecialIssue5Winter2011.aspx (accessed on 5 May 2011).

89. Uppsala Conflict Data Program. "Welcome to Department of Peace and Conflict Research." Available online: http:/ / www.pcr.uu.se/ (accessed on 4 January 2015).

90. Markusen, Eric. “Genocidal Massacres." In Encyclopedia of Genocide. Edited by Israel W. Charny. Forewords by Archbishop Desmond Tutu and Simon Wiesenthal. Santa Barbara and Oxford: ABC-Clio, 1999, p. 248.

91. Sadat, Leila Nadya. Forging a Convention for Crimes against Humanity. New York: Cambridge, 2011.

92. Drost, Pieter N. The Crime of State. Book 1: Humanicide. Book 2: Genocide. Leiden: AW Sythoff, 1959.

93. Lemkin, Raphael. Axis Rule in Occupied Europe. Washington: Carnegie Endowment for World Peace, 1944. 
94. Horowitz, Irving Louis. Genocide: State Power and Mass Murder. New Brunswick: Transaction Publishers, 1976. Revised editions under the title Taking Lives.

95. Charny, Israel W., and Chanan Rapaport. How Can We Commit the Unthinkable?: Genocide, The Human Cancer. Foreword by Elie Wiesel. Boulder: Westview Press, 1982. Paperback with title change: Genocide, the Human Cancer: How Can We Commit the Unthinkable? New York: Hearst Professional Books [William Morrow], 1983.

96. Sheleff, Leon Shaskolsky. The Bystander: Behavior, Law, Ethics. Lexington: Lexington Books, 1979.

97. Gerlach, Christian. "Extremely violent societies: An alternative to the concept of genocide." Journal of Genocide Research 8 (2006): 455-71. [CrossRef]

98. Valentino, Benjamin. Final Solutions: Mass Killing and Genocide in the 20th Century. Ithaca: Cornell University Press, 2005.

99. Travis, Hannibal. "The International Arms Trade and the Prevention of Genocide: The Law and Practice of Arming Genocidal Governments." In Impediments to the Prevention and Intervention of Genocide: A Critical Bibliographic Review. Edited by Samuel Totten. New Brunswick: Transaction, 2012, vol. 9, pp. 204-7, 218-21.

100. Travis, Hannibal. "The United Nations and Genocide Prevention: The problem of racial and religious bias." Genocide Studies International 8 (2014): 122-52. [CrossRef]

101. Fein, Helen. “Genocide by Attrition 1939-1993: The Warsaw Ghetto, Cambodia, and Sudan: Links between human rights, health and mass death." Health and Human Rights 2 (2014): 10-45. [CrossRef]

102. Harff, Barbara, and Ted Robert Gurr. "Towards empirical theory of genocides and politicides." International Studies Quarterly 32 (1988): 359-71. [CrossRef]

103. Charny, Israel W. "Escaping into Ideology." In How Can We Commit the Unthinkable?: Genocide, The Human Cancer. Foreword by Elie Wiesel. Boulder: Westview Press, 1982, pp. 111-13.

104. Kiernan, Ben. Blood and Soil: A World History of Genocide and Extermination from Sparta to Darfur. New Haven: Yale University Press, 2007.

105. Fromm, Erich. The Heart of Man: Its Genius for Good and Evil. New York: Harper \& Row, 1964.

106. United Nations. "Convention on the Prevention and Punishment of the Crime of Genocide. U.N. GOAR Res. 96 (11 Dec. 1946) 78 U.N.T.S. 277." 9 December 1948. Available online: https://treaties.un.org/doc/ Publication/UNTS/Volume\%2078/volume-78-I-1021-English.pdf (accessed on 9 December 2014).

107. Jacobs, Steven L., ed. Not Guilty? Raphael Lemkin's Thoughts on Nazi Genocide. Lewiston: Edwin Mellen Press, 1992.

108. Jacobs, Steven L. Lemkin on Genocide. Plymouth: Lexington, 2012.

109. Frieze, Donna-Lee. Totally Unofficial: The Autobiography of Raphael Lemkin. New Haven: Yale University Press, 2013.

110. Jones, Adam. “Gendercide and genocide.” Journal of Genocide Research 2 (2000): 185-211. [CrossRef]

111. Dekmajian, R. Harair. Spectrum of Terror. Washington: C.Q. Press, 2007.

112. Santoni, Ronald E. "Genocide, nuclear omnicide, and individual responsibility." Social Science Record 24 (1987): 38-41.

113. Lifton, Robert J., and Eric Markusen. The Genocidal Mentality: Nazi Holocaust and Nuclear Threat. New York: Basic Books, 1990.

114. Leslie, John. The End of the World: The Science and Ethics of Human Extinction. New York: Routledge, 1996.

115. Rees, Martin. Our Final Hour: A Scientist's Warning: How Terror, Error, and Environmental Disaster Threaten Humankind's Future in the Century-On Earth and Beyond. New York: Basic Books, 2003.

116. United Nations. "Weapons of mass destruction. First Committee 2013 Civil Society Presentations." Available online: http://www.un.org/en/sc/1540/transparency-and-outreach/outreach-events/pdf/ expert-presentation-2013-15-Rome.pdf (accessed on 12 September 2014).

117. Von Joeden-Forgey, Elisa. "Gender and Genocide." In The Oxford Handbook of Genocide Studies. Edited by Donald Bloxham and Dirk A. Moses. Oxford: Oxford University Press, 2010, pp. 61-80.

118. Smith, Roger W. "Genocide and the Politics of Rape." In Genocide Matters: Ongoing Issues and Emerging Perspectives. Edited by Joyce Apsel and Ernesto Verdeja. New York: Routledge, 2013.

119. Fournet, Caroline. "Imposing measures intended to prevent births within the group. The Actus Reus of Genocide." In Elements of Genocide. Edited by Paul Behrens and Ralph Herham. New York: Routledge, 2013, pp. 53-69. 
120. Charny, Israel W. Fiction. April 2018. Intergalactic Council for Protection of Ethnic and Planetary Human Rights and the Prevention of Genocide. Internet on the Holocaust and Genocide, Special Issue on the Seventy-Fifth Anniversary of the Armenian Genocide, April 1990, Special Double Issue 25/26, 13-14.

121. Sassounian, Harut. "Villians of our Times: Talaat, Hitler, Stalin, Amin, Pol Pot." California Courier, 12 April 1988.

122. Breyer, Daniel. "Integrity and Anxious Wonder." In The Reason of Terror: Philosophical Responses to Terrorism. Edited by Ken Crimmins and Herbert DeVrise. Leuven: Peeters, 2006, pp. 261-89.

123. Forsythe, David P., ed. Encyclopedia of Human Rights. New York: Oxford University Press, 2009.

124. Stanton, Gregory. "Could the Rwandan Genocide have been prevented? " Journal of Genocide Research 6 (2004): 211-28. [CrossRef]

125. Stanton, Gregory. "The Ten Stages of Genocide: of Genocide: Classification, Symbolization, Discrimination, Dehumanization, Organization, Polarization, Preparation, Persecution, Extermination, Denial." Available online: http:/ / www.genocidewatch.org/genocide/tenstagesofgenocide.html (accessed on 4 January 2016).

126. Melson, Robert. Revolution and Genocide: On the Origins of the Armenian Genocide and the Holocaust. Chicago: University of Chicago Press, 1996.

127. Bazyler, Michael (Chapman University, Los Angeles, CA, USA). Personal communication, 10 June 2015.

(C) 2016 by the author; licensee MDPI, Basel, Switzerland. This article is an open access article distributed under the terms and conditions of the Creative Commons Attribution (CC-BY) license (http://creativecommons.org/licenses/by/4.0/). 